\title{
THE CELL IN CULTURE
}

\author{
BY \\ HONOR B. FELL \\ From Strangeways Research Laboratory, Cambridge
}

It is now more than 50 years since Ross Harrison (1907) inaugurated the technique of tissue culture in vitro, and at the same time settled for ever the controversy as to the origin of nerve fibres; he explanted fragments of a tadpole's spinal cord in a drop of lymph spread on a coverslip sealed to a hollow-ground slide and observed the outgrowth of naked nerve fibres into the surrounding fluid. During the next few years the work of Carrel and Burrows enabled many other cell types to be grown in culture for long periods ; since then tissue culture has rapidly developed until now it ramifies far and wide into cell biology, cancer research, physiology, biochemistry, pharmacology, virology, and many other branches of science. To-day I am going to talk about the contribution that the technique has made to our knowledge of the structure and behaviour of individual living cells, as this aspect of the subject seemed the most appropriate to the present occasion.

The hanging-drop method used by Ross Harrison in his classical experiments on nerve outgrowth remains the standard technique for studying individual cells in culture. There are many different forms of hanging-drop preparation, but typically it consists of a coverslip sealed over a hollow-ground slide; the tissue fragment or explant is contained in a drop of nutritive medium, usually a mixture of plasma and embryo extract, spread on the under surface of the coverslip. When the culture is incubated at body temperature, amoeboid cells crawl out of the explant which soon becomes surrounded by a broad zone of new growth in which mitotic division is active. Every few days the tissue has to be cut out of the clot and transferred to a fresh medium or the cells degenerate.

Methods have been devised to avoid this periodic disturbance of the tissue. One is Maximow's double coverslip technique to which I shall refer later. Another is some form of continuous perfusion of the cells with an oxygenated fluid nutrient ; there are many types of perfusion chamber, but in our laboratory we use the Buchsbaum apparatus (Buchsbaum and Kuntz,
1954) in which cells can be observed with phase contrast under the highest magnifications and remain in good condition for many days.

During the early period of tissue culture only two optical methods were available for the study of living cultures: ordinary direct illumination and the dark-ground microscope. Direct illumination was the more commonly used, and with its aid many accurate and beautiful observations were made by such pioneers of tissue culture cytology as Margaret and Warren Lewis in the United States, Giuseppe Levi in Italy, and by my old chief, Dr. T. S. P. Strangeways, in this country.

Let us consider how tissue culture cells appear when viewed on the warm stage of the microscope with direct lighting. In his book published in 1924, Dr. Strangeways describes the emergence of a fibroblast from an explant of the choroid and sclerotic of a chick embryo in the following words :

"A slender process of cytoplasm is seen to protrude from the edge of the explant ; this process enlarges, the nucleus passes into it, and gradually the whole mass of cytoplasm detaches itself and passes into the medium. . . The cytoplasm of the outwandering cell appears as a clear homogeneous, jelly-like substance with no obvious cell wall, although the limits can be readily discerned. . . . The outline is constantly changing, and larger or smaller processes are thrown out and withdrawn in amoeboid movement."

He mentions rod-like mitochondria, fine granules, and fat droplets moving in the cytoplasm. There is little to be said about the nucleus of which he writes :

"The definite nuclear wall usually shown in fixed preparations is not seen in cells growing in vitro. The nucleus contains one or more irregular nucleoli, which are constantly altering in shape and size."

Nothing more can be seen in the nucleus by direct illumination.

Dark-ground illumination (Strangeways and Canti, 1926, 1927) gave a much better picture of the cytoplasm than ordinary direct lighting (Fig. 1). In a living fibroblast, bright, worm-like mitochondria could be seen wandering about the cell, constantly changing shape and sometimes break- 


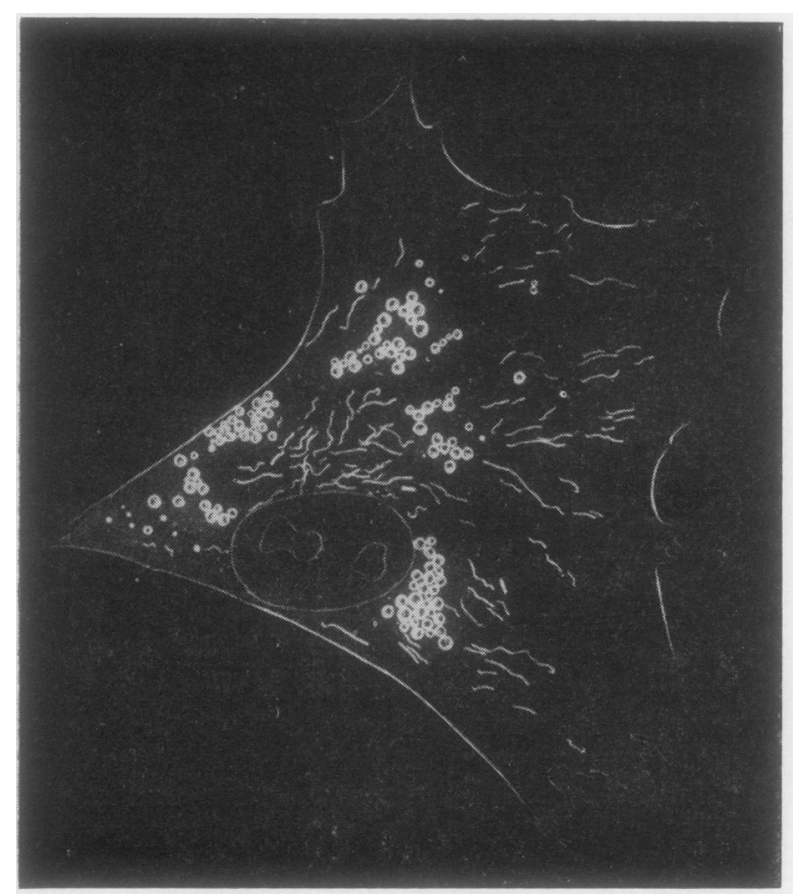

Fig. 1.-Embryonic chick fibroblast in culture, as seen by dark-field illumination. In the cytoplasm the filamentous mitochondria and fat globules are very distinct, but the nucleus appears "optically empty" apart from the two nucleoli. (Drawing by H. B. Fell; from T. S. P. Strangeways and R. G. Canti.)

ing in two; also conspicuous were the intensely refractile lipid globules and rather less bright metabolic granules. The nucleus, however, appeared optically empty, apart from the nucleoli. The dark-field method had the disadvantage that the strong light killed the cells after about 30 minutes' exposure.

The whole course of mitotic division can be followed readily by direct illumination, but not in the dark field, where the chromosomes are difficult to distinguish and are usually obscured by the refractile material in the cytoplasm of the rounded mitotic cell. I well remember my delight when, as a young research student on a visit to Dr. Strangeways' laboratory in 1922 , I saw a dividing cell in culture for the first time. My previous acquaintance with the mitotic process had been through the medium of a series of black and white diagrams which I had regarded with a certain scepticism. As I watched the living cell pass through division, I saw, rather to my surprise, that after all my textbook pictures were quite correct ; yet how utterly different was the impression made on my mind by the living, moving cell in the throes of reproduction from that conveyed by the diagrams!
During the first 20 years of tissue culture, 을 living cells were studied entirely by continuous observation on a warm stage, and very arduous $\stackrel{\rho}{\rightarrow}$ work it could be. There is a celebrated entry in $\bar{O}$ Dr. Strangeways' notebook which reads, "Cell watched for $49 \mathrm{hr}$.- did not divide." At the time he was investigating the intermitotic interval in chick fibroblasts ; sometimes they failed to undergo a second division, which was very frustrating to the observer. However, many of these vigils were rewarded with success, and Strangeways (1922) eventually recorded the mitotic interval for chick fibroblasts as between 11 and 12 hours.

Towards the end of the 'twenties, attempts were made to record the behaviour of living cells in culture in a less laborious way, by means of cinematography. A triumphant success was achieved

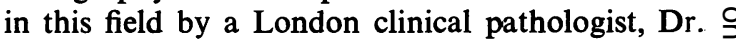
Ronald Canti of St. Bartholomew's Hospital (Canti, 1928, 1929), and I shall never forget the sensation that his film of cell migration and mitosis created when he showed it at the first Congress of Cell Biology at Budapest in 1927.

Many fascinating films of living cells followed which, when subjected to careful frame-by-framg analysis, have provided much valuable informa tion about cell behaviour. Thus, in 1931, W. H. Lewis made a ciné-record of a feature of cyto plasmic physiology, the importance of which has only recently begun to be appreciated. This was the phenomenon that he termed "pinocytosis" or $\mathbb{\perp}$ "drinking by cells."

"Certain cells in our cultures," he writes, " especially the macrophages, take in globules of fluid from the surrounding medium. . . By pinocytosis the cells are able to take in substances which cannot diffuse into them or be taken in by ordinary

phagocytosis of semi-solid particles."
Pinocytosis has now been recorded in a wide . range of cell types in culture. It has even been seen and filmed in nerve fibres, the amoeboid $₹$ ends of which ingest fluid droplets which then 0 stream up the fibre towards the cell body (Hughes, 1953). Thus speculations about the permeability of the cell membrane become rather futile when the cell can engulf globules of the fluid in which of it is bathed.

Many fine films of normal and malignant cells ${ }_{N}$ in culture have now been made, among which $\omega$ may be mentioned those of Dr. Gey and Dr. Charles Pomerat in the United States and of $\frac{O}{D}$ Professor Pulvertaft in this country.

The next major advance in the study of cells in: culture was the advent of phase-contrast micro- 0 scopy shortly after the end of the second world $\underset{D}{\stackrel{D}{D}}$ war. My former colleague, Dr. Arthur Hughes. $\frac{O}{1}$ 


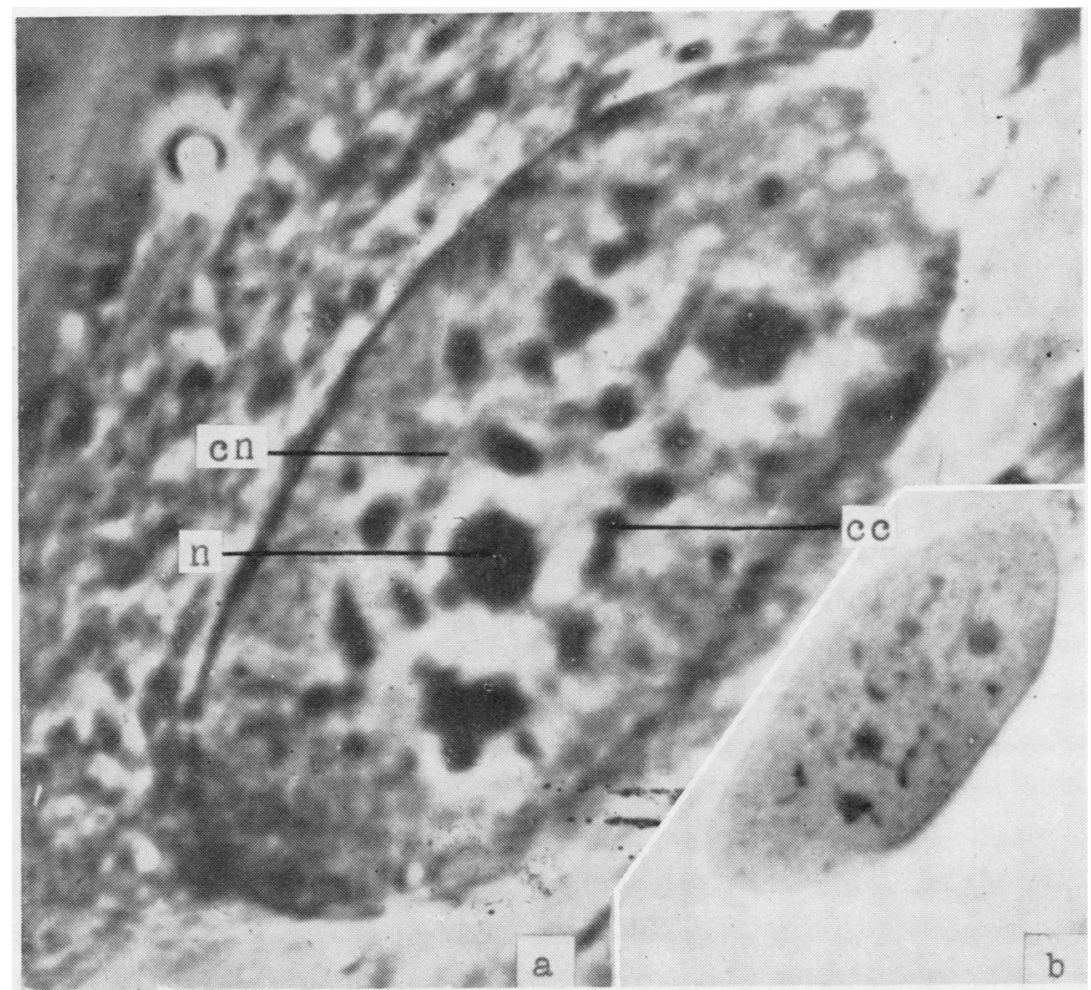

FIG. 2.-(a) Interphase nucleus in a living perichondrial fibroblast (newt), photographed by phase contrast. The chromosomal threads or chromonemata (cn), nucleoli (n), and chromocentres (cc)

was one of the first to apply phase contrast combined with cinematography to tissue culture (Hughes and Swann, 1948); he made his own phase plates and cinema apparatus, and obtained surprisingly good results with his simple equipment. Nowadays the big optical firms have developed phase-contrast microscopy to a high level of efficiency, and it has become the standard method for studying living cells in vitro.

The most striking difference between the image of the cell viewed by direct or dark-field illumination and that seen by phase contrast is in the nucleus. As I have already said, by the older methods the nucleus appears optically empty except for the nucleoli, but with phase contrast other structures are seen. Dr. Hughes and I (Fell and Hughes, 1949) investigated the interphase nuclei of mouse spleen fibroblasts in culture, and found that we could distinguish the chromosomal threads or chromonemata as fine filaments emerging from a number of refractile granules of different sizes : the chromocentres, some of which were stuck to the inner surface of the nuclear membrane and others to the nucleoli; in fixed and stained preparations the chromocentres are
Feulgen-positive. My former colleague, Dr. Jeffrey Boss (1954), found that these nuclear structures are even more obvious in the large cells of the newt (Fig. 2).

Mitosis is extremely clear in cells viewed with phase contrast (Fig. 3) and recently has been studied extensively by Dr. Boss in newt tissue cultures (1954). In this very favourable material he has been able to follow in great detail the transformation of the daughter chromosomes at anaphase into the fine chromonemata of the interphase nucleus (Fig. 4), a nice example of the structural continuity of the chromosomes postulated by geneticists.

In the cytoplasm the mitochondria and cell granules are as distinct with phase-contrast as with dark-ground microscopy. Fine cinematographic studies of living mitochondria have been made by Chèvremont and Frederic (1952) and have added greatly to our knowledge of these structures.

Of recent years the tissue culture cytologist has been provided with two more weapons: the ultraviolet and the interference microscopes. With the former, the synthesis of nucleotides can be studied quantitatively in the living nucleus, and with the 


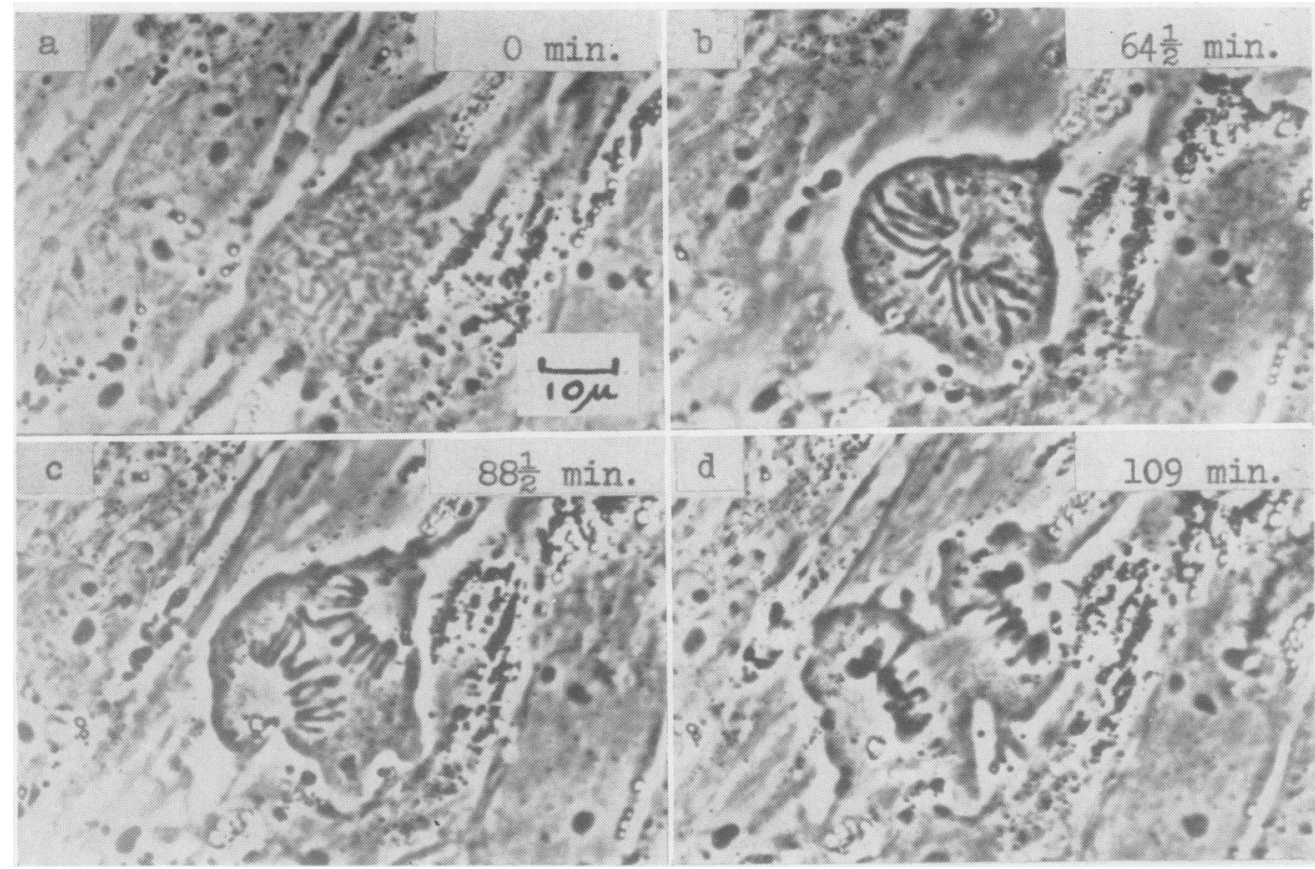

FIG. 3.-Living heart fibroblast (newt) photographed by phase contrast at different stages of mitotic division. (a) prophase; (b) metaphase; (c) anaphase; (d) telophase. $\times 800$. (J. Boss.)

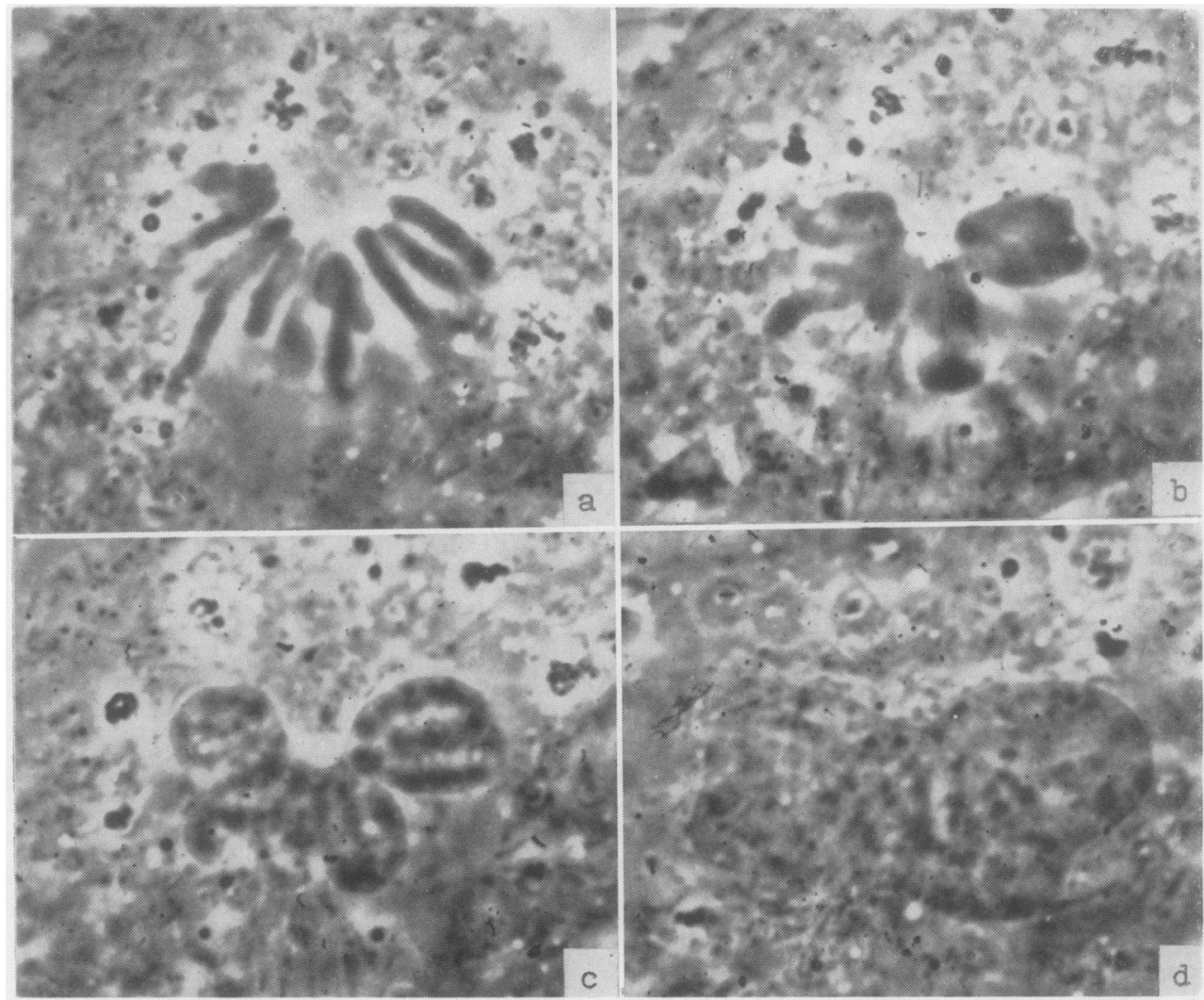

Fig. 4.-Stages in the formation of an interphase nucleus in a living perichondrial fibroblast (newt). (a) anaphase: a group of discrete daughter chromosomes are seen. (b) $12 \frac{1}{2} \mathrm{~min}$. later: the chromosomes are clumped together. (c) telophase, $20 \mathrm{~min}$. after (a); chromosomes again discrete; note transverse interchromosomal bridges. (d) $30 \mathrm{~min}$. after (a): daughter nucleus formed. $\times 1,500$. (J. Boss.) 
latter changes in dry mass in different parts of the cell can be observed.

It is possible to investigate not only undifferentiated but also differentiated cells in culture. For example, I myself (Fell and Robison, 1930) have watched osteoblasts forming bone in cultures of osteogenic mesoderm from the mandible of a chick embryo. First, very thin refractile partitions appear between the osteoblasts, then the osteogenic fibres develop and increase in number to form an intricate network around the cells. Quite suddenly the identity of the fibres becomes indistinguishable, sometimes overnight, and the osteoid matrix appears homogeneous. Soon afterwards calcification begins as a deposit of brilliantly refractile granules throughout the intercellular material.

Very interesting work on individual differentiated cells has been done by Dr. Margaret Murray and her colleagues in New York. They use Maximow's double-coverslip technique. By this method the explant and culture medium are placed on a small round coverslip which is stuck to a larger coverslip with a small drop of saline ; the big coverglass is then inverted over a large hollow-ground slide to which it is hermetically sealed in the usual way. Every few days the preparation is opened, and the little coverslip is detached and washed in physiological saline; a small quantity of fresh medium is added to the explant, and the small coverslip is placed on a clean large one which is again sealed over a hollow-ground slide. In this way cells can be maintained undisturbed for many weeks and often differentiate very well.

Murray and Stout (1954) have used this technique for the classification and diagnosis of certain human tumours, especially those of the nervous system, because they find that "intrinsic tissue characteristics may be emphasized by the changed environment of the culture, where the migrating cells are freed from the compression to which they are subject in vivo and where the cell can always be seen in its entirety."

Peterson (1950) kept embryonic ganglion cells in culture for many weeks, and during that time the long nerve fibres formed by the cells acquired their myelin sheath, a process that could be

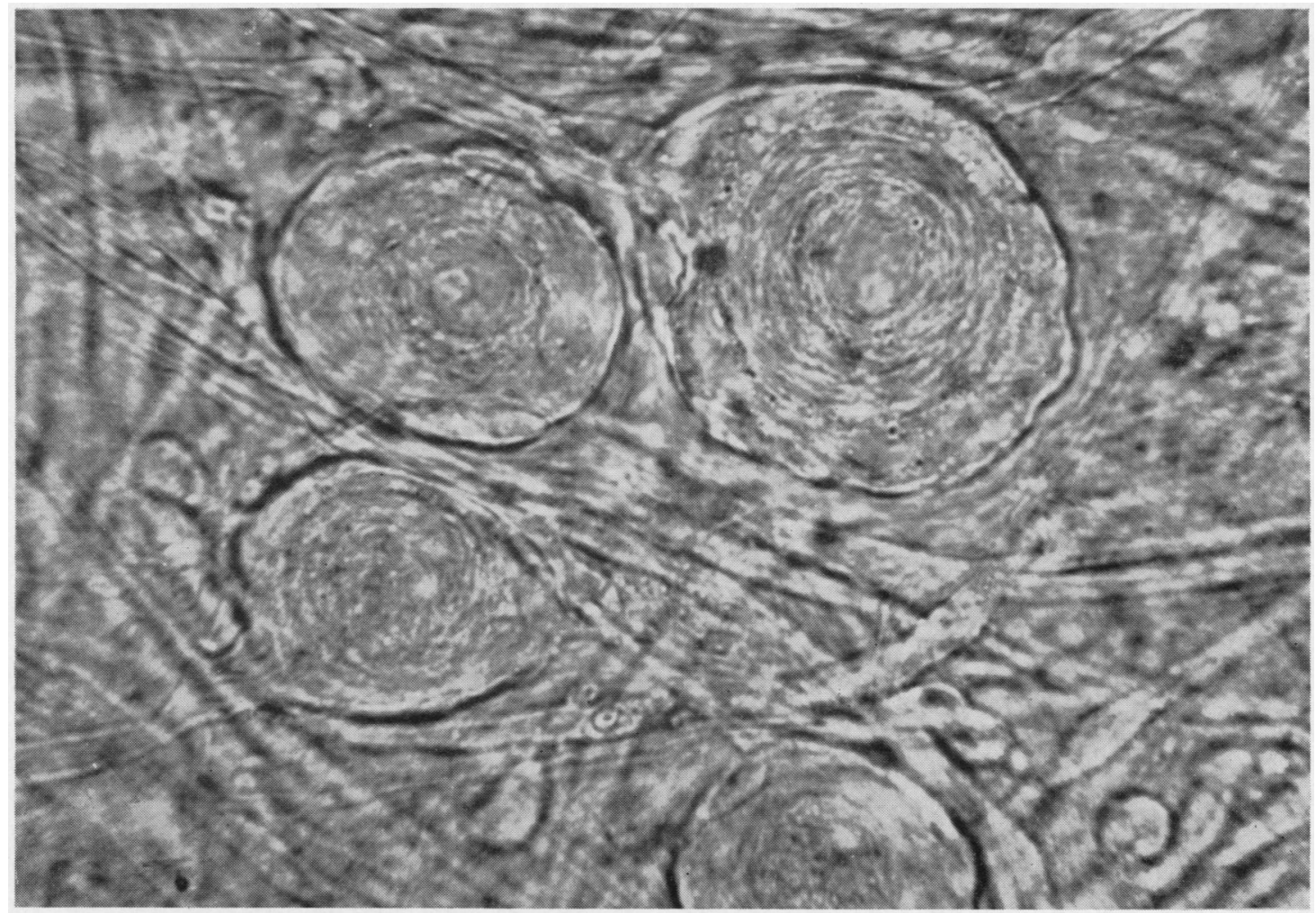

Fig. 5.-Living neurons of a dorsal root ganglion from a nine-day chick embryo; 20 days in culture. The neurons develop as large flattened discs with satellite cells and Schwann cells firmly pressed against neuronal bodies and axones. $\times 900$. (E. Peterson.) 


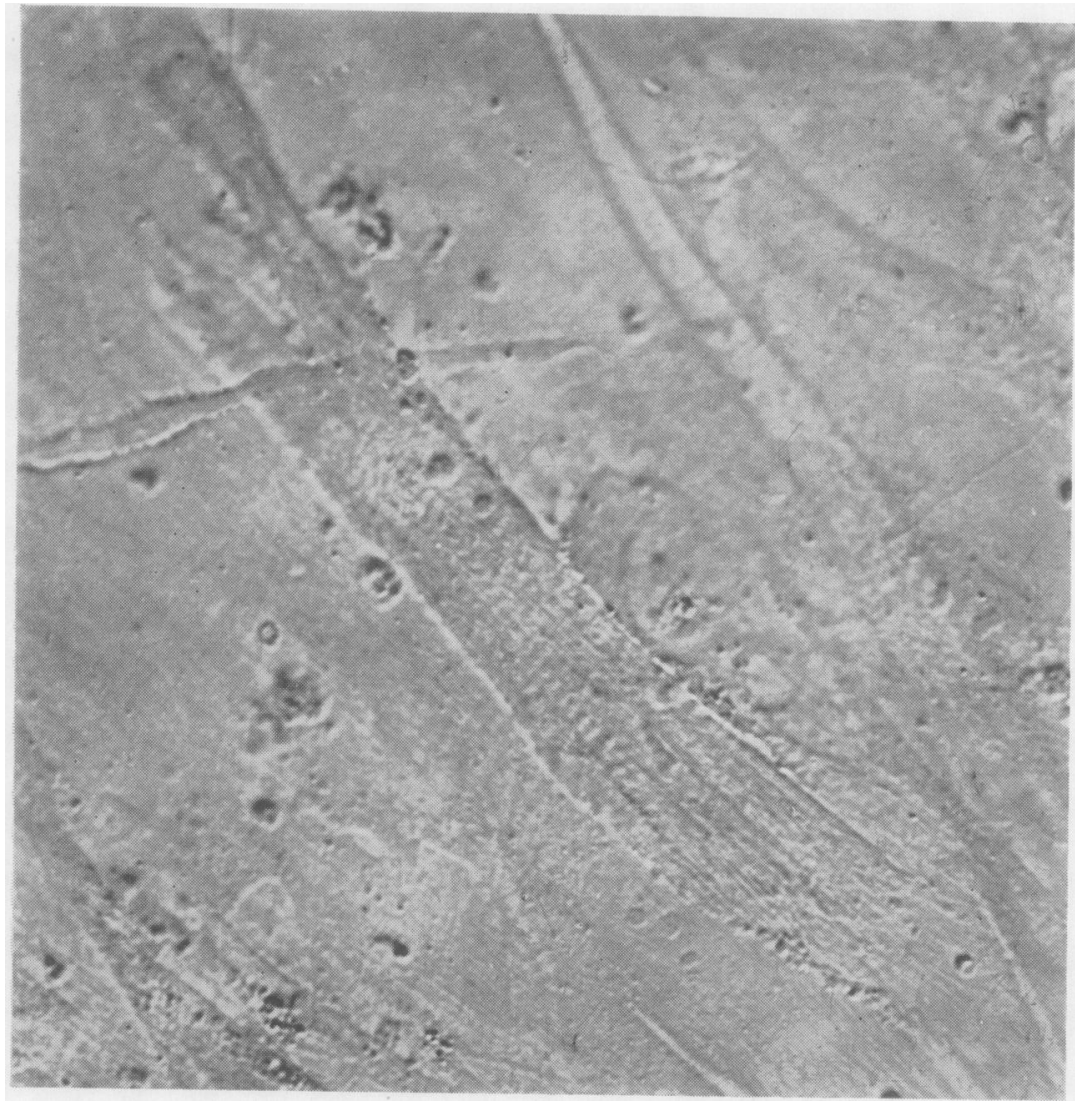

FIG. 6. - Differentiating mononuclear cell in a 30-day culture of adult human leg musclo. Fibrillae and irregular crossbanding are seen. $\times 900$. (I. A. Pogogeff and M. R. Murray.)

studied in detail in the living tissue. When $I$ visited Dr. Murray's laboratory recently, I saw one of these cultures. It was a fascinating spectacle with its large round nerve cells, in which the nucleus and Nissl substance (Deitch and Murray, 1956) could be clearly distinguished (Fig. 5 ), and long refractile myelinated fibres winding their way through the tissue. Pogogeff and Murray (1956) have grown adult human skeletal muscle for several weeks and obtained crossstriated contractile muscle fibres (Fig. 6).

The fact that individual living cells can be observed under the highest magnification not only enables normal cellular processes to be observed in life, but makes it possible to investigate the cytological effects of many experimental agents such as drugs and radiations, and also to watch the intracellular behaviour of certain viruses (cf. Bland and Canti, 1935).

In this short talk I have merely selected a few illustrative examples of the cytological aspects of tissue culture, because a review of the large literature would have been out of the question. During the past 36 years I have been able to watch the development of the subject at close quarters, and I have tried to convey to you something of the story that has unfolded before me during that time.

I am deeply indebted to Dr. J. Boss, Dr. Margaret Murray, and Dr. Edith Peterson for permission to reproduce photographs and for kindly supplying prints. I wish to thank the editors of the Quarterly Journal of Microscopical Science and the Academic Press (publishers of Experimental Cell Research) for allowing me to reproduce Figs. 1 and 2 respectively.

\section{REFERENCES}

Bland, J. O. W., and Canti, R. G. (1935). J. Path. Bact., 40, 231. Boss, J. (1954). Exp. Cell Res., 7, 215.

Buchsbaum, R., and Kuntz, J. A. (1954). Ann. N.Y. Acad. Sci., 58, 1303.

Canti, R. G. (1928). Arch. exp. Zellforsch., 6, 86. - (1929). Ibid., 8, 133.

Chèvremont, M., and Frederic, J. (1952). Arch. Biol. (Liège), 63, 109. Deitch, A. D., and Murray, M. R. (1956). J. biophys. biochem. Cytol. $2,433$.

Fell, H. B., and Hughes, A. F. (1949). Quart. J. micr. Sci., 90, 355.

and Robison, R. (1930). Biochem. J., 24, 1905.

Harrison, R. G. (1907). Proc. Soc. exp. Biol. (N.Y.), 4, 140.

Hughes, A. F. (1953). J. Anat. (Lond.), 87, 150.

and Swann, M. M. (1948). J. exp. Biol., $25,45$.

Lowis, W. H. (1931). Bull. Johns Hopk. Hosp., 49, 17.

Murray, M. R., and Stout, A. P. (1954). Tex. Rep. Biol. Med., 12, 898.

Peterson, E. R. (1950). Anat. Rec., 106, 232.

Pogogef, I. A., and Murray, M. R. (1946). Ibid., 95, 321.

Strangeways, T. S. P. (1922). Proc. roy. Soc. B., 84, 137. (1924). Tissue Culture in Relation to Growth and Differentiation. Heffer, Cambridge.

- and Canti, R. G. (1926). Brit. med. J., 2, 155.

- (1927). Quart. J. micr. Sci., 71, 1. 